\title{
Skill-based Medical English Teaching in a Corporate Environment
}

\author{
http://dx.doi.org/10.3991/ijac.v8i1.4350 \\ Jafar Asgari Arani \\ Kashan University of Medical Sciences, Iran
}

\begin{abstract}
Background: Medical English has been enjoying a good deal of popularity among doctors and medical students having an extraordinary effect on their competencies. This article proposes the use of a competency-based approach in a Blended-Learning English for Medical Purposes (EMP) course design for the students of medicine. The objectives of the study were to investigate the medical English needs of the students of medicine, to develop a BlendedLearning competency-based EMP course module for the students of medicine, and to examine the opinions of students toward the course module.
\end{abstract}

Method \& Materials: The study was a descriptive and experimental research. The course was taught using Drupal Platform and Web 2.0 tools as supplement to traditional face-to-face classroom. EMP needs were analyzed by interviewing 45 key students and a questionnaire survey with 140 students of medicine. The qualitative data from the interview were analyzed by content analysis while the quantitative data from the questionnaire survey were analyzed using descriptive statistics (mean, percentage, and standard deviation). For course evaluation, the pretest and posttest score were analyzed by comparing the mean scores of the pretest and posttest using $t$-test.

Findings: The Blended Learning course module was validated by the experts and piloted with a group of learners having the similar characteristics as the subjects in the main study. The results of $t=-15.09$ indicated that the participants in the study had higher scores in their posttest than in the pretest at a significant level $(p<.05)$. The standard deviation of all criteria ( $S D<1)$ shows that the consistency of the students opinions responses did not vary much.

Conclusion: Blended-Learning competency-based English course module can meet the needs of the students of medicine in terms of the EMP course which has conceptualized the content around the competencies needed for their studies.

Index Terms-Students of Medicine, Competency-based, Blended Learning, English for Medical Purposes

\section{INTRODUCTION}

The students of medicine should be able to communicate with excellent listening and problem solving skills, to understand and to deal with situations equipped with a high level of knowledge, strong communicative skills, autonomy, flexibility and dedication [1]. As a crucial part of the organization employees, it is essential that a special English course be designed to serve their needs so that they will be able to efficiently perform their duties[2]. A good command of English language will enable them to communicate with their counterparts around the world better on work-related issues [1]. This concept also supports the ESP vision which requires the students to have knowledge of standard phrases and emphasize English as a common working language.

From the interviews with some faculty members graduated from English speaking countries and participating it is found that there should be specific English courses provided that is specifically designed to meet the particular medical English language needs of the students of medicine in a blended manner. Based on the job characteristics of medicine graduates whose work is not on a regular office hour basis, a blended course would be a great benefit for the learners due to its "anytime-anywhere" concept with a self-pace learning. In addition, use of various digital technologies increases new learning opportunities and make learning more interesting [12]. Therefore, to better serve the needs of EMP use of students a more specially designed English course module should be developed to enhance their medical English proficiency. Hence, this research study aims to firstly, investigate the EMP needs of the students, to develop a competencybased English blended course module for them, and, lastly, to examine the opinions of the learners toward the course module.

\section{A. English for Specific Purposes (ESP) \&English for Medical Purposes (EMP)}

ESP is designed to meet specific needs of the learners; second, ESP is related in content to the particular disciplines, occupations and activities it serves; third, ESP focuses on the linguistic descriptions (grammar, lexis, register), skills, discourse and genres analysis which are appropriate to those activities. [8].ESP is an approach to language teaching in which all decisions as to the content and method are based on the learner's reason for learning". Based on the characteristics of ESP mentioned above, the key element in designing language teaching programs in ESP contexts is to base on the „learnerse and their „needse for learning English. ESP courses aim to equip the learners with a certain English proficiency level for a situation where the language is going to be used, i.e., target needs [14]; [6]; [18]; [19]. As a subcategory, English for Medical Purposes (EMP) course is designed for EFL medical students. EMP serves many purposes: to enhance the medical entrants' reading comprehension skills as well as to provide them with the basic vocabulary they need in the very beginning of their medical study; to develop the medical students' basic academic and scientific writing skills; and to give the medical students an introduction to the English medical terminology of medicine. 


\section{B. Needs Analysis}

Needs analysis combines target situation analysis (TSA) - what learners are expected to learn at the end of the language course with present situation analysis (PSA) - what learners knows already at the beginning of the course. Between the gap of PSA and PSA is ,lacks ${ }^{\text {ee }}$ - a starting point of ,what ${ }^{\text {ee }}$ and ,how ${ }^{\text {ee }}$ to learn [3]; [15]; [22]; [6].

In this study, they are needs or necessities of English language required by students of medicine as language uses; what they need to do, and how to perform to achieve a set of competencies in order to function effectively in the target situation. These needs will be transferred to tasks of language learners in English course module [15]. Needs analysis procedure can be conducted in two main categories occupying different approaches; inductive and deductive methods. Inductive methods include observations and case studies while deductive methods comprise questionnaires, surveys, interviews, diaries, previous research, pre-course placement/diagnostic tests, and final evaluation or course feedback [22];[5]. In this research study, needs analysis to outline the English language needs of students of medicine was conducted using document reviews, semi-structured interviews, a questionnaire survey and site observations.

\section{Competency and Competency-based approach}

Norton [13] proposed that ,,competency ${ }^{\text {ee }}$ is a skill performed to a specific standard under specific conditions. Competency-based approach focuses on the outcomes of learning as the starting point of the course design by identifying the tasks a learner will need to perform within a specific setting. The competencies needed for a successful task performance are identified and used as the basis of course planning [14]. According to Gatehouse [8], for second language students, the learner and what he/she will be expected to do in his/her life are the center of the teaching and learning process while the content of the academic subjects or the grammatical structure of a language comes next. Weddel [21] outlines the components of competency based education and says that the approach consists of the following:

1. An assessment of the learners ${ }^{\text {ee }}$ needs

2. The selection of the competencies

3. The target instruction

4. An evaluation of the competency attainment.

The competency based approach is characterizes by the following:

1. The competencies are stated in specific and measurable behavioral terms

2. The contents are based on the learners ${ }^{\text {ee }}$ goals, i.e. outcomes or competencies

3. The learners continue learning until mastery is demonstrated

4. The approach makes use of an unlimited variety of instructional techniques and group work

5. It centers on what the learner needs to learn, which is the application of basic skills in life skill language context such as listening, speaking, reading or writing
6. The approach makes extensive use of texts, media, and real life materials adapted to targeted competencies

7. It provides learners with immediate feedback on assessment performance

8. The instruction or teaching is paced to the needs of the learners

9. It gets learners to demonstrate mastery of the specific competency statements or objectives

\section{Blend and EMP Course Design}

The term blended learning originated in the business world in connection with corporate training [16], then was employed in higher education [14] and lastly it appeared in language teaching and learning [17]. With reference to ELT, Sharma [16] suggests 'for blended learning to be effective the two component parts should be integrated with the technology complementing and not replacing the efforts of the teacher'.

The two EMP courses take place in the two semesters of the freshman year. Both courses are credit bearing and students need a pass grade in each one to graduate.

The course was taught using Drupal Platform and Web 2.0 tools as supplement to traditional face-to-face classroom. It was chosen as one of the learning environments for the course because it met the course requirements. In addition, it is distinguished by a relative ease of use and accessibility. When designing the course, learners' needs and the skills they had were taken into consideration [20]; [11].

During the weekly face-to-face sessions, for the duration of two academic hours, students study and discuss a variety of materials, the selection of which is made based on their EMP learning needs. Then the students are offered a series of activities and exercises to help them to improve different aspects of four main language skills. Their choice is conditioned by competencies needed in the course syllabus and at the beginning of the course. The lesson outline based on the competencies needed is presented in Table 1.

\section{E. Competency Data Gathering and Analysis}

Data about the EMP needs or necessities of students of medicine were gathered through semi-structured interviews with 45 key informants to gather information about the competencies or tasks the students need to perform at their workplace, as well as to find out the opinions and expectations from the managements regarding the students of medicine competencies. The key informants consisted of 30 post graduate students of medicine (resident) to obtain common facts or practice across their study, and five faculty members/clinicians of the university chosen voluntarily.

Also a questionnaire survey was conducted with 140 students of medicine taking two three-credit EMP I\&II courses in two semesters. The survey covered the overviews of the participants ${ }^{\text {ee }}$ Medical English skills, difficulties in using English to perform their tasks, and their necessities in English language training in performing those competencies/tasks on a 5-Likert"s rating scale. The information obtained was translated into a course module. 
TABLE I.

THE BLENDED COURSE MODULE

\begin{tabular}{|c|c|c|}
\hline Section & Skill & Competencies \\
\hline 1 & $\begin{array}{l}\text { Reading com- } \\
\text { prehension: } \\
\text { Passage \& } \\
\text { dialogue scripts }\end{array}$ & \begin{tabular}{|l} 
Specific techniques used in academic \\
writing \\
- \\
Sentence (punctuations, coordination, \\
parallelism): infinitive phrase, \\
/N./Adj./Adv. clauses, abridgments \\
- Paragraph Topic sentence, Support- \\
ing sentence, conclusion... \\
- Medical Paper/Article, Abstract, In- \\
troduction, Discussion...
\end{tabular} \\
\hline 2 & Writing & $\begin{array}{l}\text { Applying techniques needed to write aca- } \\
\text { demically. } \\
\text { - Medical/academic sentences. } \\
\text { - } \text { Scientific paragraph having its own } \\
\text { elements and with specific patterns } \\
\text { (Analysis: conductive/Inductive, De- } \\
\text { scription, Analogy...) } \\
\text { - Academic medical paper, with its own } \\
\text { structure, document and argumentation } \\
\text { to present. Medical scientific article or } \\
\text { books to medical community. }\end{array}$ \\
\hline 3 & Listening & \begin{tabular}{|l} 
Listening comprehension: \\
- Sentences \\
- dialogues \\
- Passages \\
- To learn two- and three- part words, \\
double negative, idioms... \\
- Showing agreement, untrue, emphatic \\
- uncertainty... \\
Conditions.
\end{tabular} \\
\hline 4 & Speaking & \begin{tabular}{|l} 
Presenting orally to: \\
- $\quad$ Describe oneself \\
- $\quad$ a medical case \\
- $\quad$ "a research area \\
- $\quad$ Discuss a medical issue in depth
\end{tabular} \\
\hline
\end{tabular}

The course module was implemented in a blended setting with students registered to the courses. Each course consisted of a book and the time frame to complete the course was 17 weeks, one 90-minute class every week. The learners were given a four- skill pretest and posttest to measure their level of medical English proficiency. The scores comparison and end-of-course evaluation form and semi-structured interviews were conducted to evaluate effectiveness of the course module. The qualitative data from the interview and the questionnaire survey were analyzed by content analysis and descriptive statistics (mean, percentage, and standard deviation) respectively. T-test was also applied to compare the mean scores of the pretest and posttest.

\section{FINDINGS}

The results reported 8 tentative lists of need duties/tasks of students of medicine which were matched among the three key informant groups. The example duties/tasks were: to write medical academic sentences, to respond to colleagues communications on a medical case, to discuss a medical issue, to write a paragraph to introduce a situation, to listen a dialogue to understand emphasis or uncertainty, to present orally a medical area in depth, etc.

Some competencies of students of medicine were: discuss academic manuals, and medical documents; conduct fluent and appropriate English communication with academic abroad colleagues; ask and receive information about English meetings; handle and solve health problems including duties recommended by the key informants and answer inquiries in medical world by different means.

The students of medicine rated the mean of necessity of Medical English in each competency higher than 3.59. The highest rated task was "conduct fluent and appropriate English communication with academic abroad colleagues"(mean $=4.10)$, followed closely by "answer inquiries in medical world by different means" (mean $=3.90$ ) and "ask and receive information about English meetings" (mean=3.40). The lowest rated competency/task was "discuss academic manuals, and medical documents" (mean $=3.10)$.

According to the information obtained from the students about blended-learning competency-based English course module, the students of medicine enumerated the following: ease of access to the course materials (\%89), an opportunity to receive EMP materials while they are out of the university or at their free time $(\% 86)$, and to gain more confidence in their homework $(\% 71)$ thanks to the opportunity to compare their ability in four skills to those of their peers. Also, thanks to blending, students gain greater awareness of audience issues teacher and feedbacks because peers provide a broader and more natural audience for their communications (\%63).

The EMP students were pre-and post-tested their medical English proficiency. Two raters rated each participant using the scoring rubrics of English oral communication for Students of medicine. This scoring rubrics language proficiency scale highlighted six features of language skills as the criteria as follows; comprehension, interaction and personal attributions, vocabulary and expressions, structure, pronunciation and fluency [9].There are five level descriptor for each of the six criteria; Level 5 - Proficient, Level 4 - Advanced, Level 3 - Intermediate, Level 2 - Elementary, and Level 1- Pre-elementary. In this study, an inter-rater reliability analysis using the Kappa statistic was performed to determine consistency among raters. Cohen ${ }^{e e}$ s Kappa index generally ranges from -1.0 1.0 [10]. The inter-rater reliability for the raters was found to be Kappa $=0.62$ which was considered at the substantial level (0.62-0.80) [10].

The result from the pretest scores shows that the majority of the participants (between Intermediate and Advance level. None of the participants was rated at the scale of Elementary level on the posttest. Only $10 \%$ of the participants were rated at the scale between 3.0-3.60. The majority of the EMP students $(86.7 \%)$ were rated at the interval scale of Advance level. The results of $t=-15.09$ indicated that the participants in the study had higher scores in their posttest than in the pretest at a significant level $(p<.05)$. As all of the criteria of the questionnaire to survey the opinions of the students toward the course were rated above 3.5, it seems that their opinions toward it were positive. The standard deviation of all criteria $(\mathrm{SD}<1)$ shows that the consistency of the students opinions responses did not vary much.

\section{CONCLUSIONS}

According to Foyster [7], Delker [4], and Norton [13] students progress through the instructional program at their own rate by demonstrating the attainment of the specified competencies, their learning must be self-paced, they should have flexible training with a large group or 
individual study, and they should use supporting material including print, audiovisual and simulations (models) which are relevant to the Blended-Learning applied to this study. In addition, Blended-Learning module offers an opportunity to learners of different learning styles to utilize the lessons. The Blended course module allowed the learners to access the lessons at their convenient time. Due to the tight schedule of the students of medicine, they prefer taking Blended-Learning EMP course.

All the participants showed appropriate attitude/personal attribution in each posttest test. So they could master the competencies.

Some students are weaker in listening while some others were week in speaking. In the other way around, it is also found that some participants who have lower overall scores are rated higher in the feature of interaction and personal attribution because they show their interest in the reading and writing reinforcement in EMP schedule. However, they need improvement in the area of the linguistic knowledge. Thus, it is necessary that the test result should be examined in every aspects based on each criterion. Only putting an emphasis on the overall score may lead to a gap of achieving a competency.

Blended-Learning competency-based English course module can meet the needs of the students of medicine in terms of the EMP course which has conceptualized the content around the competencies needed for their studies. The course is useful in the eyes of the participants. In addition, the impact that this study has on the community of the students of medicine is that it creates a positive learning atmosphere for the staff members. Some possible directions for the improvement of the blend may include improving the criteria for assessing the students' contributions, improving the students' homework submission procedures and providing them with more opportunities for collaboration for critical considerations. This new way of building a teaching system based upon skill development while meeting the given learning goals is making teachers rethink the pedagogical paradigm, as the whole process is student-oriented and assumes the existence of a dynamic curriculum.

\section{REFERENCES}

[1] Aiguo, W. (2007). Teaching Aviation English in the Chinese Context: Developing ESP Theory in a Non English Speaking Country. English for Specific Purposes. 26,121-128. http://dx.doi.org/10.1016/j.esp.2005.09.003

[2] Beech, J.(1990). Thank You for Flying with Us: English for InFlight Cabin Attendants. UK: Prentice-Hall International.

[3] Chambers, F. (1980). A Re-Evaluation of Needs Analysis. English for Specific Journal. 1(1), 25-33. http://dx.doi.org/10.1016/02722380(80)90007-4

[4] Delker, P.V. (1990). Basic Skills Education in Business and Industry: Factors for Success or Failure. Contractor Report, Office of Technology Assessment, United States Congress Development: Ladbrook, Australia. ERIC: ED 317849

[5] Douglas, Dan. (2000). Assessing Language for Specific Purposes. Cambridge: Cambridge University Press.

[6] Dudley-Evans and St. John. (1998). Developments in English for Specific Purposes: A Multi-Disciplinary Approach. Cambridge: Cambridge University Press.

[7] Foyster, J. (1990). Getting to Grips with Competency-based Training and assessment. TAFE National Center for Research and Development.

[8] Gatehouse, K. (2001). Key Issues in English for Specific Purposes (ESP) Curriculum Development. The Internet TESL Journal 7(10): 1-10. [Online]. Available from: http://www.iteslj.org/Articles/Gatehuse-ESP. html. [November 10, 2008].

[9] Hutchinson, T and Waters, A. (2006). English for Specific Purposes. Cambridge: Cambridge University Press.

[10] Landis, J. Richard and Gary G. Koch, The Measurement of Observer Agreement for Categorical Data, Biometrics ,Vol. 33, No. 1 (Mar., 1997), pp. 159-174 http://dx.doi.org/10.2307/2529310

[11] MacDonald, J (2006) Blended Learning and Online Tutoring. Aldershot, Hampshire: Gower.

[12] Meksophawannagul, M. and Hiranburana, K. (2005). Designing Web-Based E-Learning for Management Trainees in the Banking

[13] Norton. R.E. (1987). Competency-based Education and Training: A Humanistic and Realistic Approach to Technical and Vocational

[14] Richards, J.C. (2001). Curriculum Development in Language Teaching. Cambridge: Cambridge University Press. http://dx.doi.org/10.1017/CBO9780511667220

[15] Rungirandorn, A. and Rongsa-ard, A. (2005). From Needs Analysis to course Design of Business Communication for Learners with Job.

[16] Sharma, P (2007) Try a blend that creates a new class of learning. Guardian Weekly (16 February 2007)

[17] Sharma, P and Barrett, B (2007) Blended Learning. Oxford: Macmillan.

[18] Strevens, P. (1988). ESP after Twenty Years: A Re-Appraisal. In M. L. Tickoo (Ed.), ESP: State of the Art. pp. 1-13 Singapore:

[19] Sujana, D.I.M. (2005) Establishing English Competencies for Students of Tourism Department [Online] (n.d.] Available from:

[20] Supatakulrat, L and Wasanasomsithi, P. (2005). From Needs Analysis to Course Design of English Engineers in Saraburi Province.

[21] Weddel, K.S. (2006). "Competency Based Education and Content Standards.” Northern Colorado: Northern Colorado Literacy Resource Center.

[22] West, R. (1994). State of the Art Article: Needs Analysis in Language Teaching. Language Teaching. 27 (1): 1-19. http://dx.doi.org/10.1017/S0261444800007527

\section{AUTHOR}

Jafar Asgari Arani is with Kashan University of Medical Sciences, Iran.

Submitted 22 December 2014. Published as resubmitted by the authors 10 March 2015. 